\title{
Villas In The "Underground"
}

\author{
RIEDLOVÁ Kateřina ${ }^{1, a^{*}, \text { KUBICOVÁ Věra }}{ }^{2, b}$ \\ 1,2VŠB TUO FAST Ostrava, Ludvíka Podéště 1875/17, 70833 Ostrava, CZ \\ akaterina.riedlova@vsb.cz, ${ }^{b}$ vera.kubicova@vsb.cz
}

Keywords: Socialist architecture, family house, villa, illegality, totality.

\begin{abstract}
The political changes of 1948 brought, among other things, a significant shift in the housing policy. Focus was no longer on living in detached family houses or urban villas so popular prior to 1948. On the other hand, we can also find architecturally great villa like family houses designed by professional architects. However, construction of these houses was not far from being illegal since everything was done secretly without the slightest possibility of being presented within the professional circles or the public. The investors recruited mainly from social and cultural groups of famous people with original ideas, were not acceptable to the ruling party.
\end{abstract}

\section{Introduction}

The houses were large typological theme of Czech modern architecture until WW2. First half of the 20th century preserved unusually large good fund of the houses and villas in the Czech Republic. They are the bearers of the progressive tendency on European level. Changing of political and economic conditions in 1948 caused that in our country the family villas became untouched theme not only in theoretical works but also almost unrealized type of construction for many years.

In spite of that, we can find a family houses villa of type of the architectural quality were designed by good architects and which were created for political reasons almost underground in the secret and without the possibility of presentation in this period. Their investors were most outstanding personalities of the cultural and social life, who were unacceptable to leading political class for their political views Residential architecture from this period bears no significant progressive ideas but becomes the evidence that in this strange historical period not disappears completely.

\section{Zdenek Plesník’s three villas in Zlin}

In this hardest normalization period 50s of the 20th century were created three exceptional villas of architect Zdeněk Plesník in Zlín. They are a pair of villas for travelers Miroslav Zikmund and for Jiři Hanzelka on the southern slope in Zlin from the years 1953-1955 and villa of composer Zdenek Liška from 1956 to 1959. The first one is the rebuilding of Januštík's villa. The second one standing on the neighboring property is a new monumental building, which contrast to the Zikmund's villa in all ways.

Hanzelka's villa is characterized by the monumental pyramidal symmetrical composition with an expression of dominance. Hanzelka's the villa is characterized by the monumental pyramidal symmetrical composition with an expression of dominance. The tiered character of villa is based on the natural gradient of the slope. The concept is connection between architecture and landscape and is reflected inside the house in form of gradual unfolding disposition. This is a three-storey house with partially submerged basement below the ground level. The center of gravity disposition of this house is staircase. We can find a clear parallel of Loos Raumplan here. The entrance of the house is in basement level the residential then forms a large continuous space. Jiri Hanzelk's vila had been dedicated to art - a hall for producing sound. His passion for playing the organ was famous and house was designed by wavelengths tone of this instrument. Structurally it supporting walls 
supplemented by reinforced concrete pillars [1]. The ceilings are made from concret and they are ribbed. Brickwork is complemented by elements of artificial stone. The fate of the villa Jiri Hanzelka is however the memento: In 1958 it was donated to The Czechoslovak State to the terms of use for nursery school with the operation in whole week (now children's rehabilitation center). With this is related the removal of organ and the built-in furniture. New feature requested gradually a number of construction impacts, which led to the complete devaluation of the work. When carrying out the massive building extensions in the 2000 it was destroyed, as well as untouched terrain configuration of the garden. Non-renewable is surface of the prefabricated parts of the facade [1].
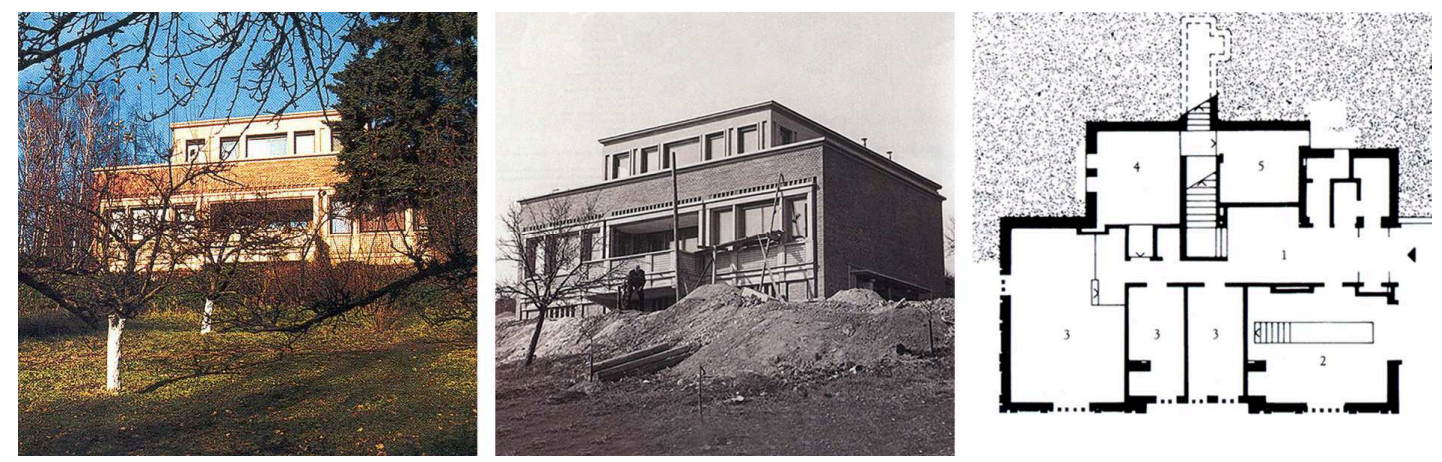

Fig. 1. Villa Jiři Hanzelka in Zlín (1956), Zdeněk Plesník

The Zigmund's villa and Hanzelka's villa villas in nearby Kudlov were supplemented by the third house from years 1956 to 58 - villa of the composer Zdenek Liska. Vila Zdenek Liska is different from the pair of Plesník villas for Hanzelka and Zikmund. It is a work subtly linking typological and architectural motifs from different eras and environments, but always with a sense of perfect stylization in favor of a new whole. Again, there is an organic connection with nature but already through allusive "Patium 's pool [1]. This is a two-story house with the basement partially sunk below ground level. Entrance into the house is in the basement level so that utilizes slope of the terrain. Ground floor of the southern wing with bay window is formed by the continuous living space, half of the living space occupied office Zdenek Liska. The east wing was the bedroom and the northern tract belongs to operator rooms. Garden of Liska's villa is fully integrated into the disposition. Linking house with the garden is realized through the portico made of stone and concrete. Structurally it is the supporing wall system. The facade of the house is the brickwork with elements of artificial and natural stone smooth plaster and the brizolit. The fate of the villa Zdenek Liska is also a memento: Zdeňek Liška sold his villa to Czechoslovak State Film. Then in 1975 it was adapted to the studio of the short and puppet film. In the mid-90s the house became a private property and ceased to be used. Due to the poor safety and to the bad maintenance the house had been destroyed during several years. The current state resembles the coarse structure [1].
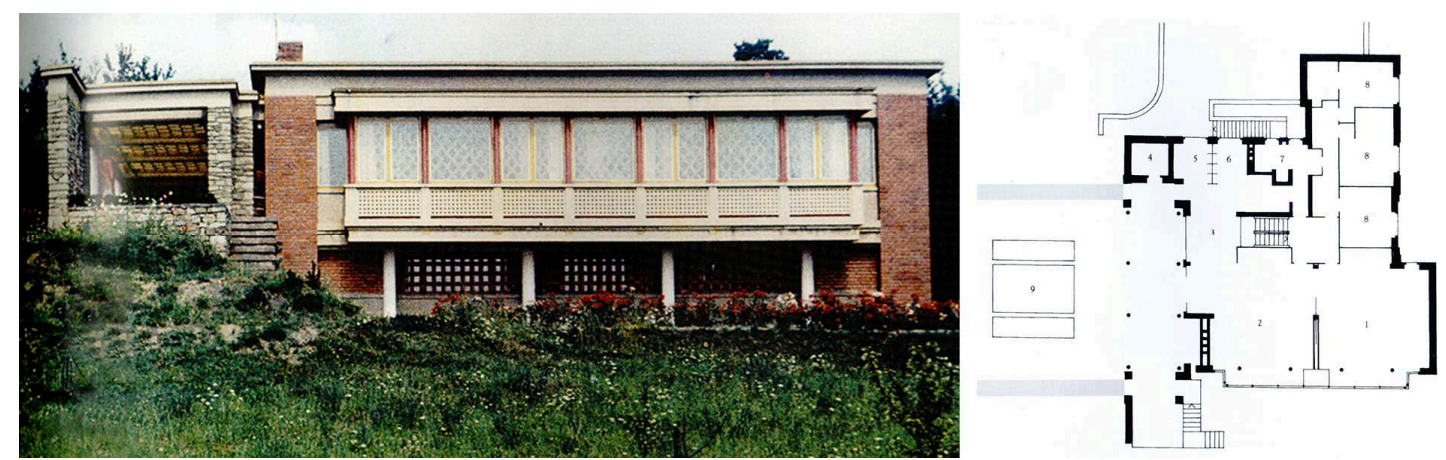

Fig.2. Villa Zdenek Liška in Zlín (1959), Zdeněk Plesník 


\section{Prague villa in the "underground"}

One of the most important implementation Prague villa the period of socialism is the villa of the film director Věra Chytilová in Prague - in Troja by architect Emil Přikryl of 1975. The villa stands on a very exposed location on the edge of the slope and the entire building is characterized by consistent inclusion the surrounding countryside. The project is based on a functionalist approach to the creation but uses an obliquely cut shapes that are typical for the house and gives it brutalist expression. The villa stands on a very exposed location on the edge of the slope and the entire building is characterized by consistent inclusion the surrounding countryside. Residential functions of the house have no end enclosed between four walls but penetrate farther into residential gardens. Views into garden provide a feeling of integration of exterior and interior. Interior spaces are well designed and they provide living conditions for a large family and creative work. Large living space is divided vertically by platforms and by built-wooden galleries. A part of completely open living space is the dining room. The private part of the house consists of two separate studio apartments (each with its own suite). On the second floor there are three bedrooms, which are also studies. Basement of the house contains a technical background, cellar, workshop and studio. Its own equipment interior have a certain amount of "bohemian romance" [2]. The villa was built by traditional technologies masonry reinforced concrete ceiling atypical windows (from standardized profiles). The smooth white plaster contrasts with the dark blue paint window frames and doors. This amazing project had been realized by creative obsession of the investor. But his tolerant approach always respected the project [3].
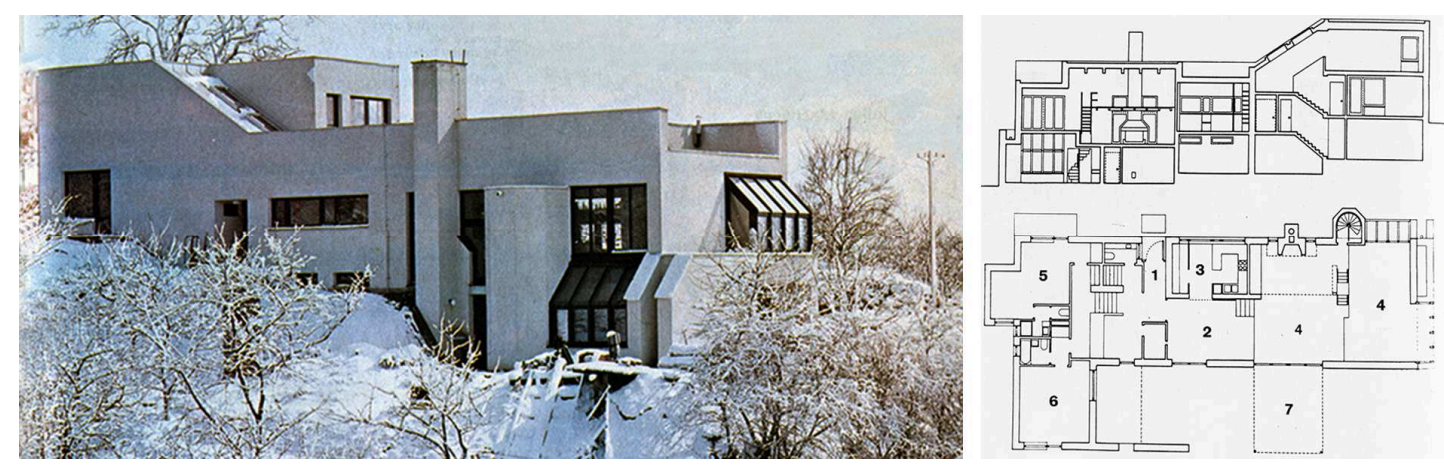

Fig. 3. Villa Věra Chytilová in Prague-Troja (1975), Emil Přikryl

The aggressive mass compositions were very close to Verra Machoninová. Little is known about her two villas, about her own house in the street Na Hřebenkách under Strahov from 1970 and about the villa for Otomar Krejča in the Šturm street in Bubeneč. Among the functionalist villas colony Baba, in the corner of the street Na Ostrohu attracts by brutalism concept Jindrich Hladky's villa from 60's. Twoperpendicular lying mass blocks gives a surprising look of the house, which was not designed by the architect, but by own builder of the house by the mechanical engineer. However the unqualified builder made his mark on inappropriate internal dispositions [4].
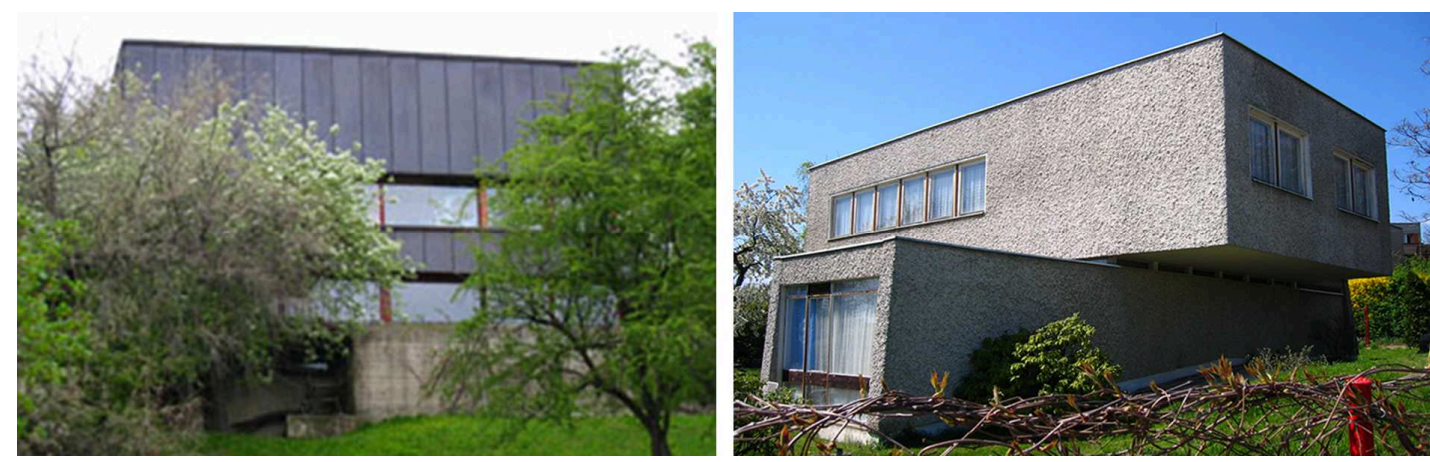

Fig. 4. Family house Eva Machoninová and the family house on Na Ostrohu, Jindřich Hladký 
Another exceptional examples of villas from Prague area is own house J. Louda and K. Prager in Bráník out of 70 years. Atypical expression gives the house cylindrical solution of the roof.

\section{Brno villa in "underground"}

The implementation of Brno houses from 60th to 80th years due to its architectural quality beyond the ordinary architectural creation are Ivan Ruller villas. His houses, thanks to the used material can age naturally and still remains modern charm. The builder of the house on the Preslova street recorded after many years o: I'm lucky that I live in the house that Ivan Ruller created. I am still enchanted by his work. If you do not believe me that the house can be magical even after 32 years after its completion, visit us [5].

House of Ing. Petráček in the street Preslova in Brno Stránice from the years 1968 to 1972 belong to the best implementations of Ivan Ruller. The building is inspired by the new brutalism, one of then the most prominent trends in the European architecture. The two-storey building masses elongated cuboid uses the slope of the terrain and Land is narrow plot and own house is hidden from the street view in the courtyard gardens. It opens up the southern facade of the garden. Architectural effect is multiplied by the landscaped garden designed by the project of significant landscape architect Ivan Otruba. On the 1st floor there is an entrance hall and utility room with the garage. Social and resting area is located in the second floor, at the same time the western part is filled by a living room with dining area and the eastern part is reserved for the bedrooms with a study and a bathroom. Structural design is based on the intention to create a space for the entire depth available to achieve variability and the opening of the south wall to the garden. Facades admit unfinished exposed concrete belonging to massive reinforced concrete grid overarching the whole building and forming a continuous parapet. It forms a characteristic expressive element along with strip windows in wooden frames The house still stands practically in its original condition without the intervention of undesirable structural modifications [5].
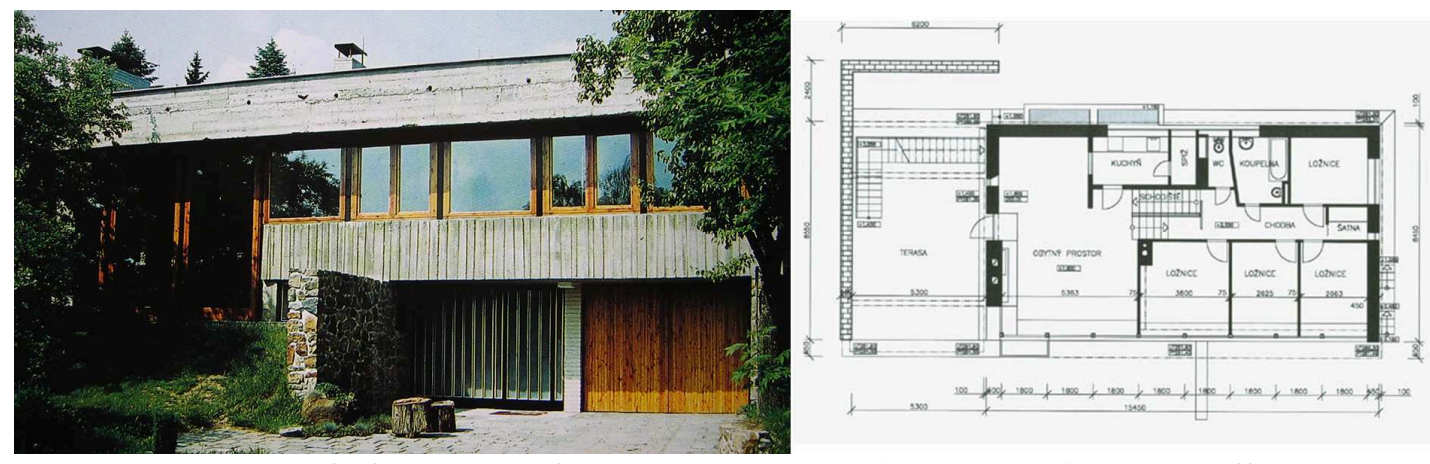

Fig. 5. Family house Preslova street in Brno (1968-1972), Ivan Ruller

House Ivanovice from 1976 by the same author is an example of how under the guidance of a qualified architect is possible to achieve good results even in buildings self-realized. With its modern simplicity the house shows undeniable artistic quality the interior and exterior. Detached house with two floors and a basement is located on the terrain break. From the simple cubic building masses are protruding color-coded buttresses. The basement contains the economic base and garage on the ground floor there is a social area and resting area. The garden facade is opened to the garden with swimming pool by glazing. Use of construction technology (the cinder blocks reinforced with steel construction) was unique at the time of construction. The building is in excellent condition, but is marked by inappropriate romantic reconstruction implemented in 90's without the knowledge of the author [4]. 

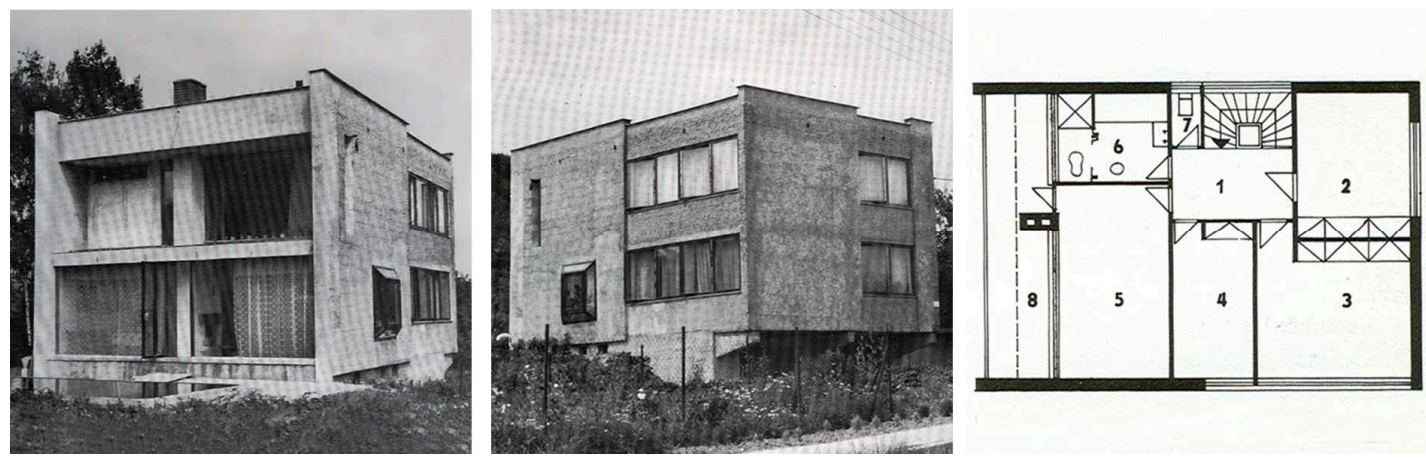

Fig. 6. House Ivanovice at Brno (1976), Ivan Ruller

Family house from 1963-1968 in Kalvodová street by architect Josef Nemec (pupil of B. Fuchs) by its simple and clean volumes sensitively enters onto the sloping land and follows the interwar tradition Brno architects House is defying against rectangular building areas of surrounding houses which are oriented into Pisárky valley with impressive views. "House is reversed toward the valley" and stands out from street line, what is underlined by dense greenery towards the street. The mass of the two-stored house consists from cube which is cutting into the slope. Social and quiet area of the house is on the 2nd floor at the entry level. In the first floor are the study and the economic background with the garage. Interior space is divided vertically and horizontally and different levels of height are articulation of importance of the room to the whole. The supporting structural system is a combination of masonry pillars and walls from solid clay bricks. Ceiling structure is from I-beams and slabs blocks and single-layer roof with surface of galvanized steel. The house has been preserved without the intervention of undesirable structural modifications in virtually original condition [4].
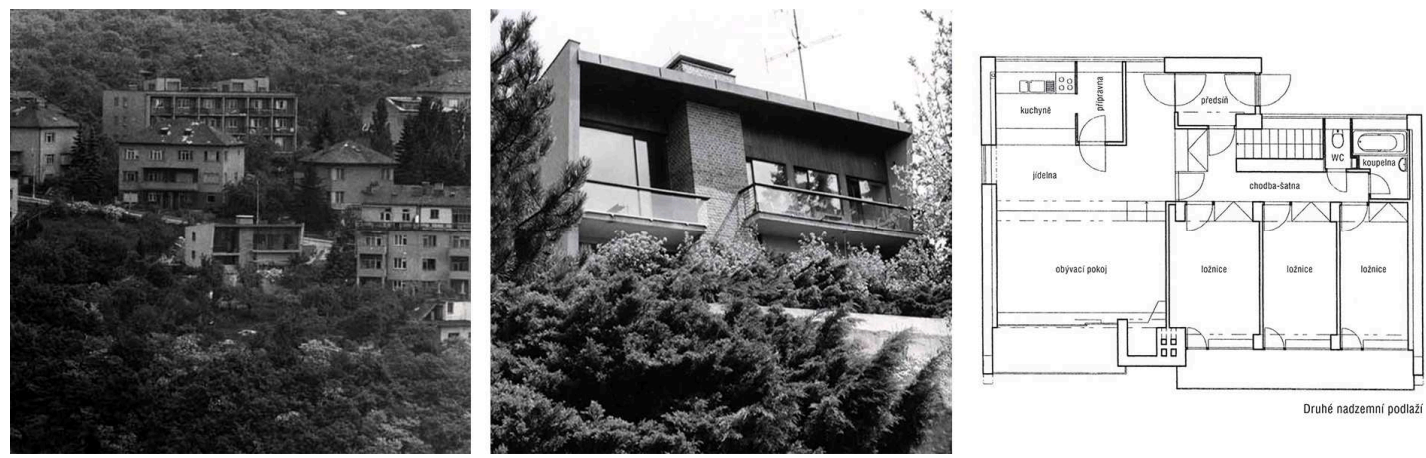

Fig.7. Family house Kalvodová street in Brno (1963-1968), Josef Němec

House Ivanovice at Brno 1979 by Miroslav Spurný is bordered on both sides of the street freestanding single-family homes mostly from the $70 \mathrm{~s}$ and the $80 \mathrm{~s}$. Basically building was created by the owners themselves. The entire mass of the house is destined by the embedded atrium in horizontal plane. The resulting built-up area has the shape of a U. The actual mass of the object, which is derived from the shape of block, is further divided in two floors. Social and quiet area of the house is located on the 1st floor. Living room with kitchen is designed as a space which is open, both into the atrium also into the street. On the 2 nd floor there is the bedroom with the bathroom. The bulk of the 2 th floor, however occupies terrace. There is a noticeable influence of Le Corbusier's villa Savoy and foremost there is consistently implemented his idea of living in generous terrace as a full-fledged space the house. Structurally it belongs to brick wall structure with partial basement. Ceiling construction is carried by crosswise mounted I-beams. Color and material of the building is very clean and simple. Steel structures in exterior (columns, I-beams, railings) are painted dark blue. Glazed surfaces without the possibility of opening are by material solved from kopilit. House has not passed yet, no major changes [4]. 

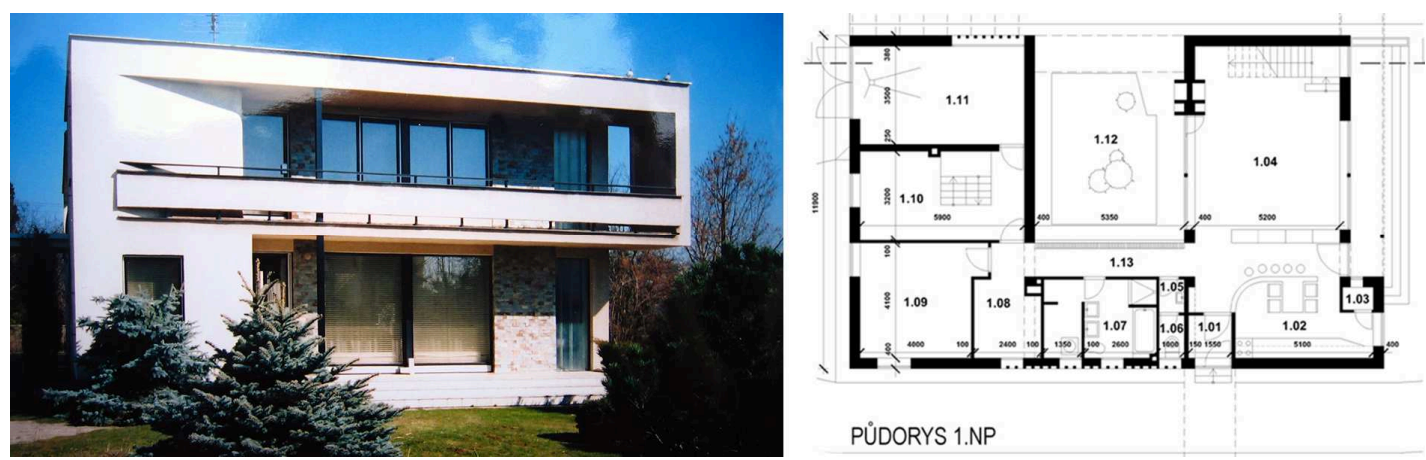

Fig.8. House Ivanovice at Brno (1979), Miroslav Spurný

Custom atrium house of architect Růžena Žertová in the street Zákoutí from the years 197981 stands on the axis of street which terminates a good distance from other condensed terraced houses of Palacky Hill. It is atrial house and consists of two basic masses in the shape of the letter L. On the front part of the house follows the mass of associated garage. The building is single-stored house without a basement with flat roof. It acts very compactly and simple, clearly dominate by the horizontal solutions. Timeless Interior prefers the "free plan" which is evidence of artistic feeling and of craftsmanship ability the architect. The house stands on piles drilled to bedrock. The cladding is designed as a sandwich. The house is in excellent condition not only due to the quality of design and overall solution but mainly due to constant maintenance and care of the owner [4].
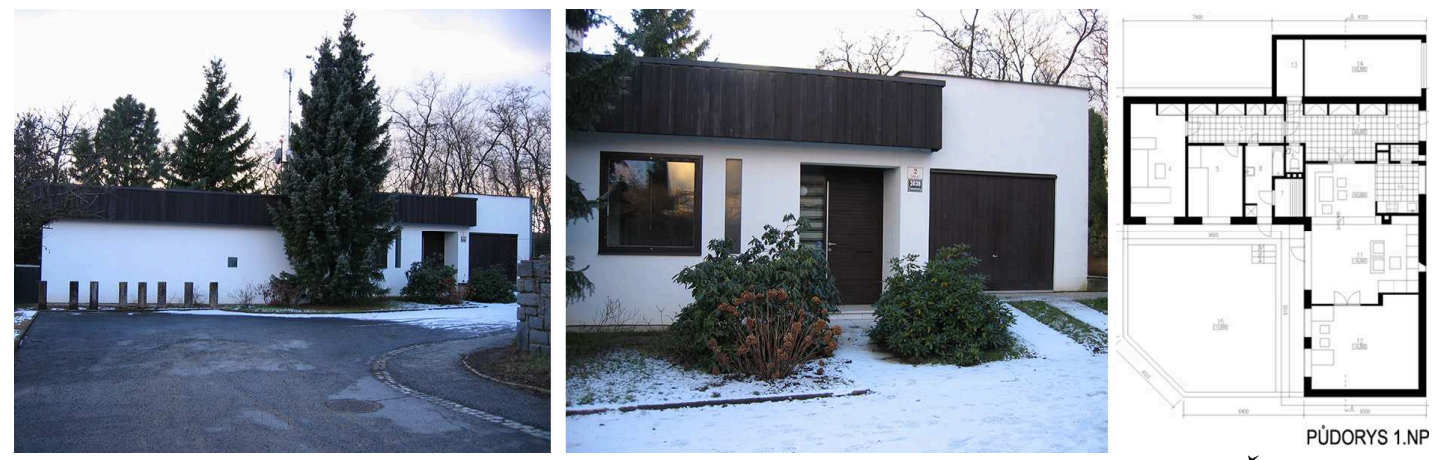

Fig. 9. Family house on the street Zákoutí in Brno (1979-1981), Ružena Žertová

\section{Conclusion}

Due to complexity social conditions in the Czech environment during communism it had been created only a little of pronounced family villas. It was more of exceptions, which confirm their high level and their high value in their expression and also in their supporting idea. These are the residential objects in no way exceptional in scope in scale no way flashy.

\section{References}

[1] Z. Plesník, 3 vily architekta Zdeňka Plesníka: Zikmundova, Hanzelkova, Liškova, (The exhibition catalog of the Jaroslav Fragner Gallery, 02.12-03.15 2001), The Jaroslav Fragner Gallery, Brno, 2001.

[2] J. Macháček, Dům roku, Bydlení - město pro člověka, in 3(1987)32-43.

[3] R. Sedláková, Vila v Tróji, Architektura ČSSR, in 9(1986)407.

[4] K. Riedlová, Individuální bydlení 60.-80. let u nás, (dissertation), Technical University Brno, 2006

[5] J. Sedlák: Slavné brněnské vily, first ed., Praha, 2006. 